\title{
FOOD SECURITY OF THE BLACK SEA LITTORAL AND FEATURES OF ITS DEVELOPMENT
}

\author{
Iryna Sedikova', Ihor Savenko², Olena Boiko³
}

\begin{abstract}
A critical review of the definition of "food security" (FS) in the context of the views of economists was conducted. The main indicators were analysed that make it possible to determine the actual food security level of the country and the region. Justified the necessity of establishing food security as a priority goal of state policy. The food security of Ukraine was considered as a derivative of anthropogenic loading on the natural environment. The aim of the article. The purpose of this study is a critical review of scientific works on the problems of assessing the food security level, calculation of food security indicators with the established rational norms of food consumption in order to analyse the existing food security system of the Ukrainian Black Sea region and the peculiarities of its development. The subject of the study is theoretical bases, methodological approaches and practical recommendations for the definition of the existing system of indicators of food security and their thresholds for foreign values. Methodology. The methodological and theoretical foundations of the research are the scientific positions of economic theory, agro-food complex, planning and forecasting, scientific publications of domestic and foreign scientists in various spheres of economic science. In order to achieve the conceptual integrity of the work, general scientific and special methods were used: analysis and synthesis - for the comprehensive study of food safety processes; systematization to identify the conditions, factors of providing food security; statistical - for generalization, systematization, and revealing of development tendencies of phenomena and processes connected with food safety of the region; graphic for the visual display of the regularities of the change of food security indicators. Results. The conducted research indicates an improvement of the status of food safety indicators. The negative aspect is the ineffective state regulation of foreign trade, the conditions for the effective development of the food market are not created, and there are no favourable conditions for increasing the production volumes of the main agricultural products types. Value/originality. The methodology for determining the indicators for assessing the state of food security, which exist at present, requires new approaches and improvements. The conducted research allowed the authors to combine indicators into groups. The research has shown that for the sake of a comprehensive, complete analysis of the state of food security, it is necessary to take into account the indicators: socio-economic, which take into account such components as level and quality of life, solvency of the population, demographic factor; macroeconomic, such as gross aggregate product, gross domestic product, personal income, because the problem is systemic and related to the development of the country and its individual regions. From the author's point of view, from the strategic perspective, Ukraine should make the transition to the food safety indicators proposed by the Committee on World Food Security (CFS). This will allow an assessment of the real state of food security, which was formed in the regions and in the country as a whole, and urgently take appropriate action to improve it.
\end{abstract}

Key words: food security, indicators, consumption, food, region.

JEL Classification: F63, 011, 012

\section{Introduction}

In the conditions of a rapidly, alternating world, development brings us not only certain advantages but also new obstacles. Mankind has reached such an extent that it is impossible to ignore the threats that humanity faces, and the problem of guaranteeing safe development at this stage becomes the main one.

The solution of painful socio-economic problems is impossible without a high level of food security. It is important to consider it as a system that consists

\footnotetext{
Corresponding author:

${ }^{1}$ Odesa National Academy of Food Technologies, Ukraine.

E-mail: sedikova@rambler.ru

${ }^{2}$ Odesa National Academy of Food Technologies, Ukraine.

E-mail: kaf.ml332@gmail.com

${ }^{3}$ Zaporizhzhia State Engineering Academy, Ukraine.

E-mail:lvbojko@yahoo.com
} 
of separate subsystems: the world, national, regional, households, and the individual. The importance of this problem is determined by the fact that the human need for food belongs to the first group, and the degree of gratification is insufficient. Since food production and the environment are interrelated, farming using outdated, non-ecological methods will lead to dangerous processes that affect the quantity and quality of natural resources, which directly affect food production, and, as a consequence, food security (Adamisin, Pukala, Chovancova et. al., 2016).

Food security is a strategic national priority with the active participation of the state, a global problem both for the country as a whole and for individual regions. The international practice of satisfying food needs justifies its sufficient level for all citizens of the world in the amount of $80 \%$ or more of the food they consume, which must be carried out by their in-house agrarian sector, which ultimately raises the indicator of the quality of life of the population and, accordingly, its replication.

FAO notes that to provide humanity, the number of which is projected 9 billion people by 2050, (a 97\% increase in population occurs in India, China, Pakistan, Nigeria, Bangladesh, Indonesia), agricultural production will need to increase by $70 \%$ (World Summit on Food Security, 2009). At the same time, measures should be taken which provide all people with physical, socio-economic access to a sufficient amount of safe food products, focusing on the security of full access for women and children.

In 2011, Ukraine adopted the law "On Food Security", which states that "food security is a socio-economic and environmental situation, in which all social and demographic groups of the population are consistently and guaranteedly provided with safe and high-quality food in the required quantity and assortment required and sufficient for the physical and social development of the individual, ensuring the health of the population of Ukraine" (Law of Ukraine "On Food Safety of Ukraine", 2011). At the World Food Summit, the following definition was given: "Food security means when a person constantly has physical, social, and economic access to sufficient, safe and healthy foods that provide their needs and food preferences for an active and healthy lifestyle" (World Summit on Food Security, 2009). The position of food security is achieved if sufficient food is provided for the entire population under normal conditions and the minimum necessary under emergency circumstances.

\section{Analysis of recent research and publications}

The scientific works of many economists are devoted to state determination question of food security and key indicators, so A. Berezin (2002) considers the features of agricultural production, its importance for the formation of food resource flows, proposals for the formation of a national food market V. Boyko (2011) consider the issues of the legal mechanism for regulating relations on food security, explore gaps in the current agricultural legislation, pay attention to the provisions on the legislative consolidation of relations on food security as a single legal institution, A. Goychuk (2004) examines the theoretical basis for the formation of the "food security" view, examines the growing food risk in the world, analyses current trends and aspects of food security, P. Sabluk (2009) reviews the concept of national food security, analyses political and innovative factors, social and mental-psychological factors of the degree of food security, M. Khorunzhiy (2003) analyses the causes and factors especially issues and patterns, the issue of food security as a component of international economic security explores the role in the economic system and its place in this structure, A. Ulianchenko (2016) substantiates the conceptual aspects of creating a stable food security system of Ukraine based on the sustainable formation of the agro-industrial complex, explores the formation of a balanced food market, A. Skidan (2006) justifies the need to establish food security as a strategic goal of regional agricultural policy, explores the conceptual foundations of the process of modelling and defining food safety indicators at the regional level, I. Irtischeva (2009) considers the activity, based on continuous innovation as the main condition for the socio-economic development, the importance of innovation and the challenges of innovation, focuses on innovation regional agro-food market and development of the region. But many problems to determine the degree of food safety remain important and require more detailed consideration and study.

The achievement of sustainable development of the region and ensuring its food security without a realistic assessment of the current situation is extremely difficult. The assessment process itself cannot ensure food security but, in fact, it should encourage regional authorities to plan and implement the necessary measures and help them to take preventive and informed decisions to achieve the aim.

\section{Food security of Ukraine is a derivative of the anthropogenic load on the environment}

The fundamental principles of the Food Security Concept of FAO include: "food security is not food selfsufficiency; a country must produce a sufficient amount of products for its own needs, if it has certain advantages; a country must be able to import the necessary volume and meet the needs of its citizens for it; governments must provide physical and economic access to safe food" (World Summit on Food Security, 2009). FAO has established a system of indicators to determine the level of food security in four areas: the availability of food-stuffs; food availability; food security stability; food consumption. 
Approximately in the same directions, forecasting the level of food security in Ukraine is built. However, it should be noted that some of the specific indicators used by FAO are not included in the forecasting system in Ukraine. So, to characterize food security, FAO uses indicators such as the famine index (calculated as the arithmetic average of the proportion of the population that is undernourished, the proportion of children under 5 years of age with underweight and children who die before reaching the age of five) production in terms of the cost per capita, an indicator of import dependence of the country, the proportion of children with growth retardation, anemia, lack of vitamin $\mathrm{A}$, iodine, and an increase in the proportion among the adult population, people who are overweight. Table 1 shows the place of Ukraine and the countries of the world, calculated on the Global Food Security Index.

Table 1

Place of Ukraine on the Global Food Security Index

\begin{tabular}{|c|c|c|}
\hline Place & Country & $\begin{array}{c}\text { Position State Global } \\
\text { Food Security Index (points) }\end{array}$ \\
\hline 1 & USA & 89,3 \\
\hline 2 & Austria & 88,4 \\
\hline 3 & Netherlands & 87,6 \\
\hline 4 & Norway & 85,4 \\
\hline 5 & Singapore & 82,1 \\
\hline 6 & Germany & 81,7 \\
\hline & France & 80,9 \\
\hline & Great Britain & 79,8 \\
\hline & $\ldots$ & $\ldots$ \\
\hline 23 & Czech Republic & 78,5 \\
\hline$\ldots$ & $\ldots$ & $\ldots$ \\
\hline 26 & Poland & 77,1 \\
\hline$\ldots$ & & 69,5 \\
\hline 29 & Hungary & \\
\hline$\ldots$ & & 60,8 \\
\hline 47 & Belarus & 56,4 \\
\hline$\ldots$ & & 53,3 \\
\hline 52 & Ukraine & 50,3 \\
\hline$\ldots$ & $\ldots$ & \\
\hline 57 & Kazakhstan & \\
\hline$\ldots$ & $\ldots$ & Azerbaijan \\
\hline 62 & & \\
\hline
\end{tabular}

Source: systematized by the authors (Data from the Food and Agriculture Organization of the United Nations, 2017)

The low amount of government allocations for scientific research in the field of agriculture and the level of gross domestic product per capita, which is twice lower than the world average, is the main determined problem. Own resources in sufficient quantity and quality, optimal volume of import operations, level, pace of development, stability of functioning of economic sectors of the country are the key to ensuring food security (Bublyk, Koval, Redkva, 2017).Economists have identified two central concepts of "food self-sufficiency" and "food independence", as well as different vectors and methods for achieving food security. To the first provision is attributed that in order to achieve the desired level it is necessary to provide for themselves fully with all groups of food products that ensure proper reproduction of the population. Note that the state ensures its independence from food imports, regardless of the natural conditions that exist, the efficiency of the division of labour within agricultural production.

The second view, which the authors share, notes the change in the main paradigm, which should occur due to balanced export-import operations in different commodity groups, can guarantee the public free access not only to their in-house but also to imported food. Globalization processes and the increasing influence of transnational companies are shown by countries that fully provide themselves with all the necessary foodstuffs. In general, the degree of their involvement in the exchange of goods is quite high. Today, this is a progressive phenomenon in international markets, since, with the right specialization of agricultural production, countries must significantly focus on the most highly efficient sectors and specialize there taking into account climatic-related and resource-related conditions. Within this framework, efficiently usage of resources is important, not the requirement of the country's compulsory self-sustainment with food to form a system. With rational international cooperation, "subsistence farming" is not further the key point at the country level, but the degree of consistency with the system of international division of labour on the most favourable conditions for each state. Only in this case, it is possible to ensure the final consumption of the population with the entire necessary "food basket" with the help of imports.

Scientists, economists acknowledge that the urgent situation of Ukraine's food security does not correspond to the level of a developed country. The main problems of this state are low incomes of the population (18.8 hryvnia, or 60 eurocents - this is the average salary per hour of work in Ukraine. According to this indicator, the state occupies the last line in Europe) and the rapid increase in food prices (according to the State Statistics Service, the greatest price increase occurred at eggs - by $53.8 \%$, sugar $(+10.5 \%)$, vegetables $(+11,2 \%)$ and fruits $(+0.3 \%)$. It should be noted that the decline in agricultural production in the 90s of the twentieth century took a spontaneous character: the overall figure has decreased over the last decade by $38 \%$, crop production - by $31 \%$, and livestock - by $49 \%$. But in Ukraine over the past few years, there have been promising developments in the agro-industrial complex of Ukraine, namely, the stable provision of the domestic market with food products, the country has entered the top three leaders in increasing the export potential of grain products. 


\section{Guidance of the economic development of the Ukrainian Black Sea littoral in conditions of food security}

The economic activity of Odesa region is mainly focused on food production. Figure 1 shows the main activities in the processing industry according to 2017 statistics.

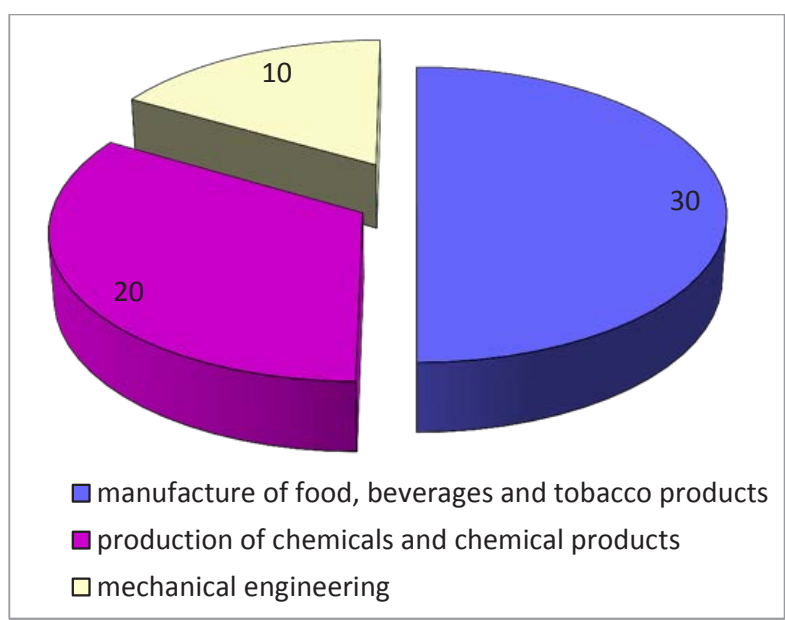

Figure 1. Main activities in the processing industry, 2017

Source: systematized by the authors (The Main Department of Statistics in Odesa Oblast, 2017)

In the "Strategy of economic and social development of Odesa region to the year 2020 " there are the following: “... in the food industry, the basic enterprises are concentrated in the oil and fat, meat and dairy, canning and wine-making industries. The main part of the production output is provided by oil and fat enterprises (Delta Wilmar CIS LLC, CJSC ADM Ilyichevsk, Bioil Universal Ukraine LLC), canning (Aquafrost LLC, CJSC PO Odesa Cannery, JV Vitmark-Ukraine, Odesa Baby Food Cannery JSC), wine-making industries (CJSC "Odesa Brandy Factory", CJSC "Odesa Champagne Wine Factory”, Odesavinprom CJSC, PTC Shabo LLC, Ovidiopolsky NPP Niva LLC) "(The Main Department of Statistics in Odesa Oblast, 2017). "In 2015, there were 6144 agricultural enterprises in the region, among them: 5153 farms, 502 household companies, 311 private enterprises, 112 cooperatives. Most of the farms are registered on the territory of Tatarbunary (684 units), Bolhrad (537 units) and Izmail (513 units) districts" (The Main Department of Statistics in Odesa Oblast, 2017).

The leading branches of crop production are grain farming, sunflower and rapeseed cultivation, vegetable growing, viticulture and horticulture. 55\% of Ukrainian grapes grow in the region. Among the livestock industries, the most developed are cattle breeding, pig breeding, poultry farming, sheep breeding. The amount of agricultural products in all categories of farms in recent years has generally tended to increase" (The Main Department of Statistics in Odesa Oblast, 2017). According to the volume of agricultural production, in particular, grain crops, the leading ones are Tarutyne, Bilhorod-Dnistrovskyi, Artsyz, Sarata, Bolhrad and Tatarbunary districts. The leaders in the cultivation of vegetables, fruits and berries are Biliaivka district, the most part of all grapes is grown in Bilhorod-Dnistrovskyi, Bolhrad, Tarutyne districts of Odesa region.

The overwhelming volume of livestock products in Odesa region is produced by local households. The largest volumes of livestock and poultry sold for slaughter were distinguished by Lymanskyi, Artsyz and Berezivka districts; Milk - by Berezivka, Liubashivka, Shyriaieve; eggs - by Kiliia, Bilhorod-Dnistrovskyi, Izmail districts of Odesa region. "According to the area of farmland, which is in the use of agricultural enterprises and population, Odesa region ranks first among other regions. The area under crops increased from 1,772.8 thousand hectares in 2010 to $1,850.0$ thousand hectares nowadays. At the same time, the share of acreage under grain and leguminous crops varies at the level of 65\%, and under sunflower-20\%" (The Main Department of Statistics in Odesa Oblast, 2017).

In the Passport of Odesa region, 2017 (the Passport of the Odesa region 2017), noted that at the end of 2017 in the Odesa region grain crops were collected on an area of 1,188.1 thousand hectares. The gross grain harvest amounts to $4,239.6$ thousand tons ( $96.3 \%$ of the 2016 level), the yield is $35.7 \mathrm{c} / \mathrm{ha}$, including wheat collected in 2278.8 thousand tons (107.9\%), barley 1266.3 thousand tons ( $84.6 \%$ ), corn 495.0 thousand tons (81.2\%).Sunflowerharvested on an area of 452.9 thousand hectares. The gross yield is 901.8 thousand tons $(89.8 \%$ by the year 2016 level), the yield is $19.9 \mathrm{dt} / \mathrm{ha}$. Rape is collected on an area of 110.0 thousand hectares. The gross yield is 258.7 thousand tons ( $340.8 \%$ ), the yield is $23.5 \mathrm{c} /$ ha. Vegetables are collected in an area of 22.1 thousand hectares. The gross yield is 287.7 thousand tons ( $82.5 \%$ ), the yield is $130.4 \mathrm{c} / \mathrm{ha}$. Potatoes are harvested in an area of 35.3 thousand hectares. The gross yield is 393.0 thousand tons $(72.6 \%)$, the yield is $111.5 \mathrm{c} / \mathrm{ha}$ (Passport of the Odesa region, 2017).

The formation of strategic directions of achievement a high level of food security of the country has systemically integrated nature, which depends on the macro-, microeconomic indicators of the development of the state and regions. In the research that is being studied, the basic document is the Law of Ukraine "On Food Security". The Law of Ukraine "On Food Security" (Law of Ukraine "On Food Safety of Ukraine", 2011) noted that "indicators of food security are a characteristic of the level and pattern of consumption of basic foodstuffs by the population, their economic affordability, the capacity of the domestic food market, sufficiency of state food resources and food independence" (Law of Ukraine "On Food Safety of Ukraine", 2011). In our opinion, indicators are vectors of development that indicate the border of adverse impacts, signalling to market actors about possible negative segments, a decrease in the global level of food security. 


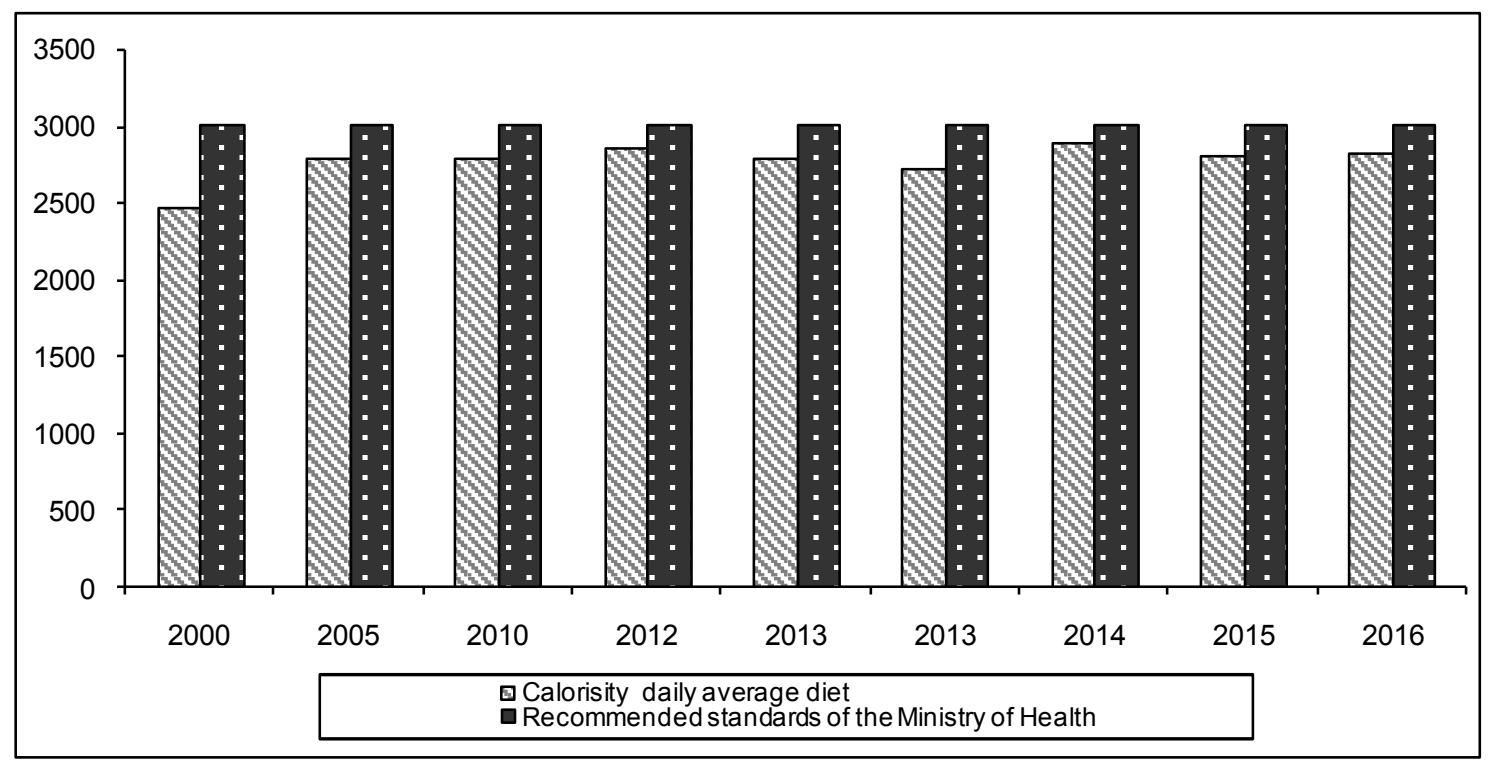

Figure 2. Dynamics of average daily consumption of food in Odesa region per person

Source: systematized by the authors (State Service of Statistics of Ukraine, 2016)

\subsection{Daily energy value of the human dietary}

The analysis revealed the following: in 2016, the average daily energy value of consumed products by residents of Odesa region was $2283 \mathrm{kcal}$, which is 10 percent lower than the recommended norm ( $3000 \mathrm{kcal})$, which is 1.7 percent less than it was in 2015. The dynamics of the average daily energy value of consumed products by residents of Odesa region per person (State Statistics of Ukraine, 2016) is shown in Figure 2. These statistics show that fruits, vegetables, berries, cereals, herbs, nuts, juices make up the bulk of calorie intake and only $30 \%$ of the average daily ration is replenished by canned meat, meat-vegetable and fish, cheese, milk and dairy products, children's products food, margarine, fats, sausages, meat concentrates, it is twice lower than the accepted rate of consumption (56\%).

Further, in Table 2, an indicator for ensuring the human dietary of the main types of products is calculated. It is acceptable when the ratio of the real and the established norm is 1 . The analysis allows to state that the balance of consumption of basic foodstuffs in the Odesa region during 2000-2016, in all groups, is lower than the standards established by the Ministry of Health of Ukraine. The unsatisfactory situation has developed with the consumption of such products as meat, meat products, milk, dairy products, fruits, berries and grapes.

It should be emphasized that the actual consumption rate of "bread products" is more than rational, which is the result of unbalanced nutrition of the population, which tries to replenish personal energy needs through cheaper food products. This is a consequence of insufficient agricultural production, low solvency of the population of certain social groups.
The sufficiency of grain stocks in public resources. The Law of Ukraine "On State Support of Agriculture of Ukraine" stipulates that "...the state intervention fund must be formed in the amount of not less than 20 percent of domestic consumption" (Article 9).

In 2016-2017 In Ukraine, a record grain harvest of 66 million tons was harvested, which is twice as more than the domestic needs, in particular, the production of wheat is 26 million tons against $9,400,000$ tons (2.77 times more than needs). The optimal quantity of grain reserves in the state reserve is calculated by the ratio of the volumes of food grains in the state reserve and the volumes of domestic consumption of bread and bread products converted in grain:

$$
O P T_{z}=\frac{Z_{r r}}{C V C} * 100 \%
$$

where $O P T z$ is the optimal level of food grains in the reserve fund; $\mathrm{Zrr}$ - the amount of grain in reserve; $C V C$ - the volume of domestic consumption of bread and bread products converted in grain;

The critical level of the indicator is its $17 \%$ level. The annual demand of Odesa region for food grains is 72 thousand tons, including 38.3 thousand tons for the rural population, for baking enterprises of all forms of ownership corresponds to the limit (60 days) and is 6.6 thousand tons.

The economic affordability of food is the share of all food expenses in the total result of household expenditures (the critical level of this indicator is 60\%). Total household spending in Odesa region amounted to 8852.2 UAH/month (Main Department of Statistics in Odesa region, 2017). 
Table 2

Calculation of the indicator of the adequacy of food consumption of the population in Odesa region for 2000-2016

\begin{tabular}{|c|c|c|c|c|c|c|c|c|c|c|c|c|c|}
\hline \multirow[b]{2}{*}{ Name product } & \multirow{2}{*}{ 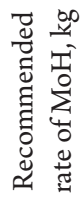 } & \multicolumn{2}{|c|}{2010} & \multicolumn{2}{|c|}{2012} & \multicolumn{2}{|c|}{2013} & \multicolumn{2}{|c|}{2014} & \multicolumn{2}{|c|}{2015} & \multicolumn{2}{|c|}{2016} \\
\hline & & 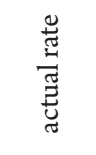 & 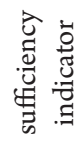 & 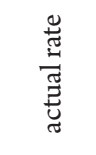 & 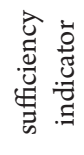 & 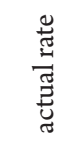 & 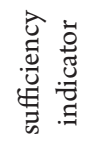 & 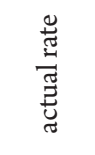 & 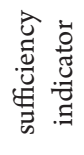 & 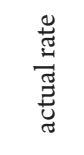 & 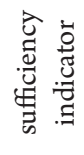 & 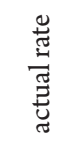 & 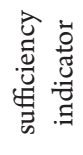 \\
\hline Meat and meat products & 83 & 45,0 & 0,535 & 46,77 & 0,555 & 48,11 & 0,575 & 48,90 & 0,587 & 45,99 & 0,548 & 47,19 & 0,565 \\
\hline Milk and dairy products & 380 & 184,59 & 0,487 & 185,35 & 0,487 & 192 & 0,505 & 205,49 & 0,537 & 194,5 & 0,509 & 188 & 0,487 \\
\hline Eggs & 290 & 282 & 0,968 & 290 & 0,99 & 292 & 1,025 & 293 & 1,026 & 279 & 0,957 & 272 & 0,939 \\
\hline Bread products & 101 & 112 & 1,122 & 113,11 & 1,115 & 108,3 & 1,057 & 108,3 & 1,058 & 103,5 & 1,028 & 103,5 & 1,029 \\
\hline Potatoes & 124 & 101,5 & 0,814 & 102,9 & 0,828 & 101,9 & 0,819 & 115,1 & 0,925 & 109 & 0,878 & 111 & 0,901 \\
\hline $\begin{array}{l}\text { Vegetables and gourds } \\
\text { food crops }\end{array}$ & 161 & 147,6 & 0,915 & 171,3 & 1,058 & 166,8 & 1,035 & 173 & 1,067 & 169,5 & 1,047 & 161,1 & 0,99 \\
\hline Fruits, berries and grapes & 90 & 58,2 & 0,647 & 60,1 & 0,669 & 59,9 & 0,668 & 58 & 0,635 & 60,2 & 0,669 & 55 & 0,609 \\
\hline Fish and fish products & 20 & 18,6 & 0,928 & 17,7 & 0,888 & 17,7 & 0,888 & 15,7 & 0,785 & 12 & 0,589 & 13 & 0,658 \\
\hline Sugar & 38 & 36,1 & 0,948 & 37,2 & 0,978 & 37,2 & 0,977 & 37,2 & 0,976 & 37,1 & 0,978 & 34,7 & 0,908 \\
\hline Oil & 13 & 15,4 & 1,178 & 14,2 & 1,085 & 14,1 & 1,075 & 14,1 & 1,078 & 14,1 & 1,078 & 13,2 & 1,017 \\
\hline $\begin{array}{l}\text { Calorie of an average } \\
\text { daily dietary }\end{array}$ & 3000 & 2839 & 0,947 & 2872 & 0,958 & 2843 & 0,948 & 2888 & 0,958 & 2801 & 0,924 & 2723 & 0,908 \\
\hline
\end{tabular}

Source: calculated by the authors (The Main Department of Statistics in Odesa Oblast, 2016)

Table 3

The balance of production and usage of grain, thousand tons

\begin{tabular}{|c|c|c|c|c|c|c|c|c|c|c|c|c|c|c|c|}
\hline & \multicolumn{10}{|c|}{ The balance of grain and leguminous crops in agricultural enterprises in 2016} & \multicolumn{5}{|c|}{$\begin{array}{c}\text { The balance of grain processing } \\
\text { products in agricultural } \\
\text { enterprises in } 2016\end{array}$} \\
\hline & \multicolumn{3}{|c|}{ Receipt } & \multicolumn{7}{|c|}{ Usage } & \multicolumn{2}{|c|}{ Receipt } & \multicolumn{3}{|c|}{ Usage } \\
\hline & \multirow{2}{*}{ 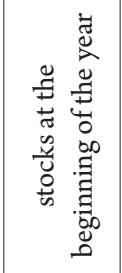 } & \multirow[b]{2}{*}{ 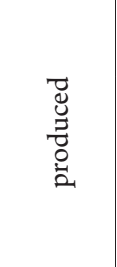 } & \multirow{2}{*}{ 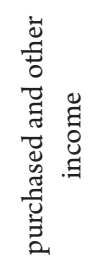 } & \multirow[b]{2}{*}{ 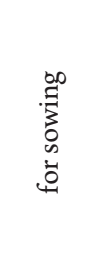 } & \multirow[b]{2}{*}{ 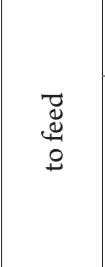 } & \multicolumn{2}{|c|}{ for processing } & \multirow{2}{*}{ 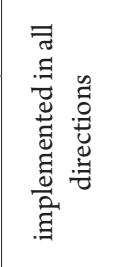 } & \multirow[b]{2}{*}{ 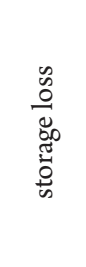 } & \multirow{2}{*}{ 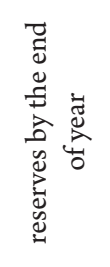 } & \multirow{2}{*}{ 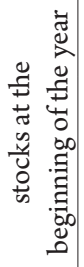 } & \multirow{2}{*}{ 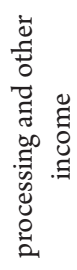 } & \multirow[b]{2}{*}{ 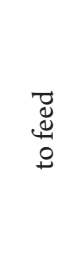 } & \multirow{2}{*}{ 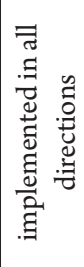 } & \multirow{2}{*}{ 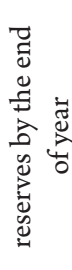 } \\
\hline & & & & & & 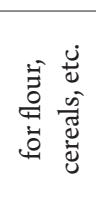 & 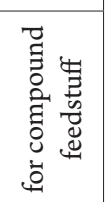 & & & & & & & & \\
\hline Ukraine & 15288,7 & 52022,2 & 6849,9 & 1705,7 & 1203,5 & 1029,3 & 2352,6 & 47348,1 & 305,3 & 20216,3 & 72,6 & 849,5 & 618,1 & 210,3 & 93,7 \\
\hline $\begin{array}{l}\text { Odesa } \\
\text { region }\end{array}$ & 651,9 & 3319,8 & 54,1 & 164,5 & 73,4 & 38,3 & 32,8 & 2856,2 & 11,0 & 849,6 & 2,8 & 38,5 & 21,6 & 12,4 & 7,3 \\
\hline
\end{tabular}

Source: calculated by the authors (State Service of Statistics of Ukraine, 2017)

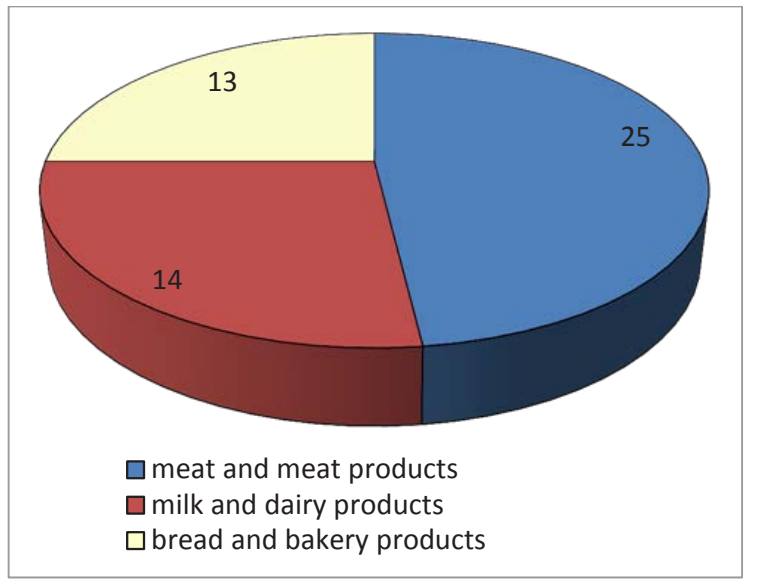

Figure 3. The General Structure of the Cost of Food

Source: systematized by the authors (State Service of Statistics of Ukraine, 2017)
Household spending on food is $4892.7 \mathrm{UAH} /$ month. The indicator, which is analysed in 2017, was 57 percent. Figure 3 shows the overall structure of food expenditure.

\subsection{The distribution of the cost of food by social groups}

In 2017, about twenty percent of households with incomes above the average spent for food 2904.39 UAH/month, and twenty percent with lower incomes - 1758.6 UAH. The coefficient, which is being investigated, amounted to 1.678 in 2017 and 1.676 in 2016, respectively. The World Health Organization notes that an able-bodied person should increase consumption of dairy products - by $8 \%$, meat (mainly chicken) - by $20 \%$, fruit - by $61.9 \%$, consumption of confectionery products should be reduced to $1 \mathrm{~kg}$ per month. 


\subsection{The capacity of the domestic market for certain products}

Despite the decrease in population, the capacity of the domestic market for all food groups increased. The research proved that there is an increase in demand for those food groups whose consumption lags behind the optimal norms (meat, dairy, and fish products).

\subsection{Food independence for certain products}

Providing consumers with a sufficient amount of the main food groups, taking into account their level of solvency, is carried out by producing domestic products. In 2017, imports from European countries amounted $\$ 413,800,000$ (28.2\% of the total imports of goods in the region), from other countries $\$ 105,210,000$, or $71.8 \%$ (in 2016 - $\$ 350.7$ million or $28.1 \%$ and $\$ 896.3$ million or $71.9 \%$, respectively).

Table 4

Commodity structure of import receipts of some foodstuff groups, 2017

\begin{tabular}{|l|l|l|}
\hline \multicolumn{1}{|c|}{ Product group } & \multicolumn{1}{|c|}{$\begin{array}{c}\text { Import } \\
\text { volume, mln. } \$\end{array}$} & $\begin{array}{c}\text { Increase, } \\
\%\end{array}$ \\
\hline Plants products & 147,6 & 14,0 \\
\hline Fats and oils of animal/vegetable origin & 126,9 & 10,7 \\
\hline Fish and fish products & 295,7 & 7 \\
\hline Vegetable oil of all kinds & 74,36 & 22 \\
\hline
\end{tabular}

Source: systematized by the authors (State Service of Statistics of Ukraine, 2017)

The share of fish and fish products imports in the dietary consumption of the population is $73 \%$. According to the "vegetable oil of all kinds" position, a large share of imports is associated with the import of tropical oils (palm oil 90\%), which are not typical for production in Ukraine but are used for the production of food and non-food items. Domestic demand for sunflower oil Ukraine is fully provided by its own production. The largest share of imports in 2017, which is more than $70 \%$, of fruits and berries, were such types of fruits: citrus fruits, bananas, dates, pineapples, mangoes, avocados, and so on.

\subsection{Density of highways}

The ease and speed of foodstuff delivery to the population depend on the concentration of roads per unit of area. $27 \mathrm{~km}$ of roads per $100 \mathrm{~km}^{2} \mathrm{~S}$ (square) were accounted in Ukraine in 2016, this figure is one of the lowest in Europe.

Odesa region is located on the crossing of five international transport corridors: the seventh and ninth Cretan corridors, the transport corridor (EuropeCaucasus-Asia), the "The Baltic Sea - The Black Sea" corridors and The Black Sea Transport Ring. $41,600,000$ tons of cargo were transported by 2017 , which is 5.4\% more than in 2016. In 2017, the Odesa Commercial Sea Port exceeded 24,136.6 thousand tons of cargo (95.6\% of the 2016 result), including: exports $-17,494$ thousand tons (- 8\%), imports - $4346(+19 \%)$, transit 2176 thousand tons $(-15 \%)$. Transshipment of dry cargo 9516 thousand tons (99\%), liquid bulk - 2325 thousand tons (899\%), packaged ones $-12,295.38$ thousand tons (94.5\%). In the structure of cargoes, the main share is: grain - 7650 thousand tons (93.3\% in comparison with 2016), containers -6969 thousand tons (104\%), ferrous metals -5170 thousand tons.

\section{Conclusions}

The research indicates an improvement in the status of food security indicators. The negative point is the ineffective state regulation of external trade, the conditions for the effective development of the foodstuff market are not created, there are no favourable conditions for increasing the volume of manufacturing of the main types of agricultural products. A necessary condition is to minimize the deviations of actual consumption volumes towards the normative, increasing the level of effective demand by the population. There are two vectors for achieving food security in Ukraine: 1) ensuring the supply of food in amounts that guarantee healthy and nourishing food of the population; 2) as well as the support and protection by the state of domestic producers. It can be stated that the optimal approach to understanding the problems of food security should be based not only on creating bases for own food production in the country, but also on the formation of such a balance of domestic and imported food resources, which will ensure a constant level of social stability in society.

Methods for determining indicators for assessing the state of food security, which are currently used, require new approaches and improvements. The research allowed the authors to calculate individual indicators of food security in selected regions. The research proved that for a comprehensive, complete analysis of the situation, such indicators should be taken into account as : socio-economic factors that take into account such components as the level and quality of life, the solvency of the population, the demographic factor; macroeconomic, such as gross aggregate product, gross domestic product, personal income, because the problem is systemic in nature and is associated with the development, food and economic security of the country, and indeed its individual regions.

From the authors' point of view, from a strategic perspective, it is advisable for Ukraine to make a transition to the system of food security indicators proposed by the Committee on Food Security (CFS). This will allow carrying out an evaluation of the real situation of food security in the country and its regions and urgently taking appropriate actions to improve it. 


\section{References:}

Adamisin, P., Pukala, R., Chovancova, J., Novakova, M., Bak, T. (2016). Fullfilment of environmental goal of the strategy Europe 2020. Is it realistic? In SGEM 2016, BK 2: Political Sciences, Law, Finance, Economics and Tourism Conference Proceedings. Vol II. STEF92 Technology.

Berezin, O. V. (2002). Food safety of Ukraine. Kiev: Vyshha shkola.

Bojko, V. I., Kozak, O. A. (2011). On some aspects of food security and global trends in problem solving. 5 International Scientific and Practical Conference. Kiev: $\mathrm{NNCz} \ll \mathrm{IAE}$. (in Ukraine)

Bublyk, M., Koval, V., Redkva, O. (2017). Analysis impact of the structural competition preconditions for ensuring economic security of the machine building complex. Marketing and Management of Innovations, 4, 229-240. doi: $10.21272 / \mathrm{mmi} .2017 .4-20$.

Gojchuk, O. I. (2004). Food safety: Zhytomyr: Polissya.

Irtyshheva, I. O. (2009). Food safety. Economy of agroindustrial complex, 9, 39-43.

Law of Ukraine «On Food Safety of Ukraine». (n.d.). rada.gov. - Retrieved from: http://w1.c1.rada.gov (in Ukraine) Methodology for determining the main indicators of food security (2007) (n.d.) rada.gov.ua. Retrieved from: http://zakon1.rada.gov.ua (in Ukraine)

Passport of the Odesa region 2017. (n.d.). oda.odessa.gov.ua. Retrieved from: http://oda.odessa.gov.ua/statics/ pages/files/5ad4588a865b7.pdf (in Ukraine)

Sabluk, P. T. (2009). Food safety of Ukraine. Economy of agroindustrial complex, 10, 3-7.

Skydan, O. V. (2006). Food safety: Ukraine economy, 3, 53-60.

Strategy of economic and social development of the Odesa region up to 2020. (n.d.). oblrada.odessa.gov.ua. Retrieved from: http://wp-content/uploads/32-VII.pdf (in Ukraine)

Ulyanchenko, O. V. (2016). Food security is the basis of the national security of the state. Retrieved from: http://humanright.org.ua/blogs/prodovolcha_bezpeka (in Ukraine)

World Summit on Food Security, Rome, November 16-18, 2009. (n.d.). fao.org. Retrieved from: http://www.fao.org/fileadmin/templates/wsfs

Xorunzhyj, M. J. (2003). Food security: Economy of agroindustrial complex, 6, 9-16. (n.d.). ukrseeds.org.ua. Retrieved from: http://ukrseeds.org.ua (in Ukraine) 